\title{
ZnO:Cu Thin Films and p-n Homojunctions Grown by Electrochemical Deposition
}

\author{
A.P. Samantilleke ${ }^{1}$, M. Sahal ${ }^{2}$, M. Tortosa ${ }^{2}$, M. Mollar ${ }^{2}$, B. Marí ${ }^{2}$, M.F. \\ Cerqueira $^{1}$, L. Rebouta ${ }^{1}$ and M. Vasilevskiy ${ }^{1}$ \\ ${ }^{1}$ Centro de Física, Universidade do Minho, Braga 4710-057, Portugal \\ ${ }^{2}$ Department de Física Aplicada-IDF, Universitat Politècnica de Vàlencia, \\ Camí de Vera s/n, 46022, Vàlencia, Spain
}

\begin{abstract}
ZnO}$ doped with $\mathrm{Cu}$ thin films were deposited on indium tin oxide coated glass substrates by electrodeposition using an electrolyte consisting of $\mathrm{Cu}$ and $\mathrm{Zn}$ perchlorates dissolved in dimethylsulfoxide. The $\mathrm{Cu} / \mathrm{Zn}$ ratio measured in the thin films is about twice the $\mathrm{Cu} / \mathrm{Zn}$ ratio present in the starting electrolyte. Irrespective of the $\mathrm{Cu}$ content, all the $\mathrm{ZnO}: \mathrm{Cu}$ films exhibit a hexagonal wurtzite structure typical of $\mathrm{ZnO}$ with a preferential orientation along (002) direction. The p-type behaviour of $\mathrm{ZnO}: \mathrm{Cu}$ films is inferred from the change in the sign of the photocurrent observed for $\mathrm{Cu}$ concentrations greater than $2 \%$. Furthermore, a p-n homojunction with a rectifying factor $\sim 22$ were prepared by electrodepositing of $\mathrm{ZnO} / \mathrm{ZnO}: \mathrm{Cu}$ layers.
\end{abstract}

Keywords: $\mathrm{ZnO}$, p-type, electrodeposition.

PACS: 68.35.bg; 73.40.Lq

\section{INTRODUCTION}

Growth of p-type $\mathrm{ZnO}$ with low-resistivity has so far been found challenging and seen by some as controversial [1]. However, credible results of bluegreen light emission have been reported with a $\mathrm{p}$ $\mathrm{ZnO} / \mathrm{n}-\mathrm{SiC}$ device fabricated by molecular beam epitaxy where $\mathrm{Cu}$ has been the p-type dopant for $\mathrm{ZnO}$ [2]. A reliable low-cost fabrication of p-type $\mathrm{ZnO}$ will be a significant step in realizing the full potential of $\mathrm{ZnO}$. Electrodeposition (ED) is low-cost process compared to conventional deposition techniques that can be used to deposit $\mathrm{ZnO}$, as we have demonstrated recently with related materials $[3,4]$. In the present work, p-type $\mathrm{ZnO}$ thin films were synthesized electrochemically by incorporating $\mathrm{Cu}$ in $\mathrm{ZnO}$, and $\mathrm{p}-\mathrm{n}$ homojunctions based on $\mathrm{ZnO} / \mathrm{ZnO}: \mathrm{Cu}$ were also fabricated by the same method.

\section{EXPERIMENTAL DETAILS}

$\mathrm{ZnO}: \mathrm{Cu}$ thin films have been deposited on indium doped tin oxide (ITO) coated glass substrates by ED using an electrolyte consisting of $\mathrm{Cu}$ and $\mathrm{Zn}$ perchlorates dissolved in dimethyl sulfoxide (DMSO), where $0.1 \mathrm{M}$ Potassium perchlorate $\left[\mathrm{KClO}_{4}\right]$ was used as a supporting electrolyte. The electrolyte solution was saturated with $\mathrm{O}_{2}$ by bubbling molecular $\mathrm{O}_{2}$ into the electrochemical cell. The $[\mathrm{Cu}] /[\mathrm{Zn}]$ ratio of the starting solution was varied between 0 and $4 \%$ maintaining the sum of $\mathrm{Cu}$ and $\mathrm{Zn}$ cations at $25 \mathrm{mM}$. All chemicals were A.C.S. reagents, supplied by Sigma Aldrich and used without previous purification

\section{RESULTS AND DISCUSSIONS}

The composition of $\mathrm{ZnO}: \mathrm{Cu}$ thin films was determined by Energy Dispersive Spectroscopy (EDS). The $\mathrm{Cu} / \mathrm{Zn}$ ratio in the solid films was found to be twice that present in the starting electrolyte, which is related to the higher diffusion coefficient of $\mathrm{Cu}$ compared with $\mathrm{Zn}$ in DMSO.

Regardless of the different $\mathrm{Cu}$ content, $\mathrm{ZnO}: \mathrm{Cu}$ films exhibit a hexagonal wurtzite structure typical of $\mathrm{ZnO}$ with a preferential orientation along (002) direction. However, a small shift was observed for the (002) peak position, which suggests the substitution of $\mathrm{Cu}$ in $\mathrm{Zn}$ sites. The wurtzite structure is maintained for samples deposited from electrolytes containing a $\mathrm{Cu} / \mathrm{Zn}$ ratio below $4 \%$. Higher $\mathrm{Cu}$ contents degrade the 
crystallinity of the films and the wurtzite structure is no longer observed.

Figure 1 shows the RT micro-Raman spectra of $\mathrm{ZnO}: \mathrm{Cu}$ films, recorded on a Jobin-Yvon T64000 spectrometer in the frequency range of $200-800 \mathrm{~cm}^{-1}$, using the $488 \mathrm{~nm}$ excitation line of an Ar+ laser and a backscattering geometry. The presence of the nonpolar optical phonon (E2-high) mode at $437 \mathrm{~cm}^{-1}$ in the spectra confirms the $\mathrm{ZnO}$ structure with small crystallites. As can be seen, with doping, the E2 (high) mode widens and the A1(E1) mode increases in intensity and shifts towards lower wave numbers. Interestingly, we see the presence in all samples of the peak at $327 \mathrm{~cm}^{-1}$, although well resolved for sample $\mathrm{ZnO}: \mathrm{Cu}(1 \%)$ which is assigned to the second order Raman scattering arising from zone-boundary phonons $\mathrm{E} 2(\mathrm{M})$ of $\mathrm{ZnO}$. The normalized intensity ratio E2/A1 decreases strongly from approximately 0.2 (for $\mathrm{ZnO}$, $\mathrm{ZnO}: \mathrm{Cu}(1 \%)$ and $\mathrm{ZnO}: \mathrm{Cu}(2 \%))$ to 0.03 for $\mathrm{ZnO}: \mathrm{Cu}$ $(4 \%)$.

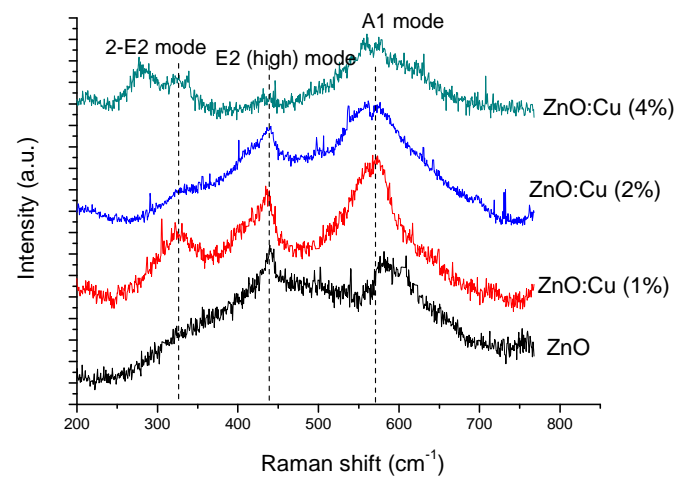

FIGURE 1. Micro-Raman spectra for $\mathrm{ZnO}: \mathrm{Cu}$ electrodeposited films.

The conductivity type of $\mathrm{ZnO}: \mathrm{Cu}$ films were evaluated using a photoelectrochemical (PEC) method. In particular, the sign of the photocurrent is the key parameter to determine the type of conductivity. The photocurrent of $\mathrm{ZnO}: \mathrm{Cu}$ films registered in a three electrode configuration using $\mathrm{KCl}$ electrolyte confirms the films are $\mathrm{n}$-type for a $\mathrm{Cu} / \mathrm{Zn}$ ratio below $2 \%$ and $\mathrm{p}$ type as this ratio surpasses $2 \%$. The p-type character of $\mathrm{ZnO}: \mathrm{Cu}$ was further assessed for $\mathrm{Zn}: \mathrm{Cu}$ ratios 100:2 and higher. A p-n homojunction diode was fabricated by depositing a $\mathrm{ZnO}: \mathrm{Cu}$ layer on top of an undoped $\mathrm{ZnO}$ layer. As the $\mathrm{ZnO}$ layer is intrinsically n-type, the rectifying behaviour of the diode further confirms the p-type doping. The I-V characteristics of such electrochemically prepared $\mathrm{ZnO} \mathrm{p}$ - $\mathrm{n}$ diode is shown in Figure 2. In the forward bias, two distinct regions are observed. At low voltages, the current (I) is linear with the applied voltage (V) (ohmic behaviour) and at higher voltages I $\alpha \mathrm{V}^{2}$, indicating the domination of space-charge limited current. This I-V characteristic follows the standard diode equation for forward bias below $0.35 \mathrm{~V}$ as given by, $\mathrm{I}=\mathrm{I}_{0}(\exp (\mathrm{qV} / \mathrm{nkT})-1)$, where $\mathrm{n}$ is the ideality factor, $\mathrm{q}$ is the electronic charge, $\mathrm{k}$ is the Boltzmann constant and $\mathrm{T}$ is the temperature. Rectification factors for the best ITO/ZnO/ZnO: $\mathrm{Cu} / \mathrm{Au}$ diode were 3 and 22 for \pm 1 and $\pm 2 \mathrm{~V}$, respectively.

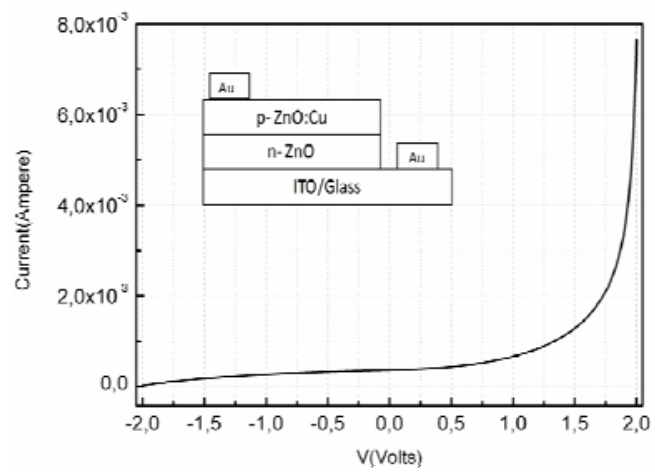

FIGURE 2. $\mathrm{I}-\mathrm{V}$ curve of a $\mathrm{ZnO} / \mathrm{ZnO}: \mathrm{Cu}$ homojunction.

\section{CONCLUSIONS}

$\mathrm{Cu}$-doped $\mathrm{ZnO}$ thin films were synthesized by an electrochemical approach. The $\mathrm{Cu} / \mathrm{Zn}$ content in the films was found to be proportional to the $\mathrm{Cu} / \mathrm{Zn}$ cation ratio in the starting electrolyte solution. A transition between $n$-type to p-type behaviour was observed in $\mathrm{ZnO}: \mathrm{Cu}$ films as the $\mathrm{Cu} / \mathrm{Zn}$ ratio surpasses $2 \%$. The $\mathrm{p}$ type character of the $\mathrm{ZnO}: \mathrm{Cu}$ films allows the fabrication of $\mathrm{p}-\mathrm{n}$ homojunctions by subsequent electrodeposition of two $\mathrm{ZnO} / \mathrm{ZnO}: \mathrm{Cu}$ layers.

\section{ACKNOWLEDGEMENTS}

This work was supported by the Spanish Government through MCINN grant MAT2009-14625C03-03.

\section{REFERENCES}

1. M. D. McCluskey and S. J. Jokela, J. Appl. Phys. 106, 071101 (1-13) (2009).

2. J. B. Kim, D. Byun, S. Y. Ie, D. H. Park, W. K. Choi, JW. Choi and B. Angadi, Semicond. Sci. Technol. 23 095004 (1-6) (2008).

3. M. Tortosa, M. Mollar, B. Marí, J. Crystal Growth 304, 97-102 (2007)

4. M. Tortosa, M. Mollar, B. Marí, F. Lloret, J. Appl. Phys. 104, 033910 (1-5) (2008). 